\title{
Perceived destination image of Poland: an analysis based on Ukrainian and Russian perceptions
}

\begin{abstract}
The purpose of this article is to compare the perceived destination image of Poland as seen by Russians and Ukrainians. This study contributes to understanding the process of how the image of a destination is shaped, the new contribution being the comparison of the image of Poland as perceived by visitors and non-visitors of two nations, which until 1991 were a part of one state. The study is based on a questionnaire consisting of 16 statements on the perceived destination image of Poland. A 5-point Likert scale was used in the survey. A total of 710 people were examined, including 348 Russians and 362 Ukrainians. The reliability of the survey was assessed using Cronbach's alpha index. The hypotheses verification, using Student's t-test, showed that Russians and Ukrainians perceived Poland as an attractive country in terms of tourism. No major differences between Russians and Ukrainians were observed in the perception of Poland as a tourist destination. Moreover, no influence of past experience was noted on the shaping of the perceived destination image of Poland. Additionally, some managerial implications of significant relevance to destination marketing are discussed, and future directions for research are outlined.
\end{abstract}

\section{Keywords} non-visitors

(c) University of Warsaw - Faculty of Geography and Regional Studies
Perceived destination image $\cdot$ Poland $\bullet$ Russians $\cdot$ Ukrainians $•$ visitors $•$

\author{
Wioletta Kamińska $\mathbb{C}^{1}$ \\ Mirosław Mularczyk $\mathbb{C}^{1}$, \\ Magdalena Chrapek $\mathbb{C}^{2}$, \\ Lidiya Dubis $\mathbb{C}^{3,4}$, \\ Marta Malska $\mathbb{C}^{5}$, \\ Evgeny Nesterov $\mathbb{C}^{6}$ \\ 1 Institute of Geography and Environmental Sciences, \\ Faculty of Natural Sciences, Jan Kochanowski University \\ of Kielce, Kielce, Poland \\ e-mail: wioletta.kaminska@ujk.edu.pl \\ e-mail:miroslaw.mularczyk@ujk.edu.pl \\ ${ }^{2}$ Department of Mathematics, Faculty of Natural Sciences, \\ Jan Kochanowski University of Kielce, Kielce, Poland \\ e-mail: magdalena.chrapek@ujk.edu.pl \\ ${ }^{3}$ Institute of Mathematics, Informatics and Landscape \\ Architecture, Faculty of Natural Sciences and Health, \\ The John Paul II Catholic University of Lublin, Lublin, Poland \\ ${ }^{4}$ Department of Geomorphology and Paleogeography, \\ Faculty of Geography, Ivan Franko National University of \\ Lvov, Lvov, Ukraine \\ e-mail: lida.dubis@gmail.com \\ ${ }^{5}$ Department of Tourism, Faculty of Geography, \\ Ivan Franko National University of Lvov, Lvov, Ukraine \\ e-mail:malskym@ukr.net \\ ${ }^{6}$ Department of Geology and Geoecology, \\ Faculty of Geography, Herzen State Pedagogical \\ University of Russia, St. Petersburg, Russia \\ e-mail: nestem26@mail.ru \\ Received: 3 September 2020 \\ Accepted: 15 February 2021
}

\section{Introduction}

In the first two decades of the 21 st century, tourism became one of the most important sectors of the world economy (Kandampully 2000; Cherifi et al. 2014). According to the World Travel and Tourism Council (2018), tourism was valued at USD 8.27 trillion in 2017 , which accounted for over $10 \%$ of GDP. Many practitioners and scientists believe that effective tourism can increase national and regional income and employment (Chen \& Tsai 2007) and improve the living conditions of local communities. This is why most countries focused on developing tourism, which in turn increased competition between regions and tourist destinations (Joppe et al. 2001). In such conditions, ways of attracting new tourists and encouraging regular visitors to return are crucial to the success of tourism development (Chen \& Tsai 2007).

Tourist destinations invest in building a positive image to help distinguish them from competitors on the market (Baloglu \& Mangaloglu 2001). Creating a favourable image of the destination means a competitive advantage can be achieved (Baloglu \& McCleary 1999; San Martin et al. 2008).

In literature, it is assumed that the image of a destination has a huge impact on tourists' decisions (Baloglu \& McCleary 1999; Echtner \& Ritchie 2003; Beerli \& Martin 2004). As Krippendorf (1982) indicates, a tourist's perception of a destination may be more important than its tangible attributes. A tourist goes to a destination to experience the image they hold of it, and not the reality. It is easier to distinguish destinations with a positive image compared with those of competitors. Tourists more often consider and choose destinations with a stronger and positive image (Lopes 2011). If a potential destination is to achieve success in the tourism industry, it must focus on developing a positive image (Baloglu \& McCleary 1999).

Tourism has been developing dynamically in Poland since the 1990s. In 2017, its share of GDP was at the level of $6 \%$. The number of foreign visitors to Poland in 2017 was over 80 million, and the number of tourist arrivals was 17.5 million (Polish Tourism Organisation 2020). According to the Polish Tourism Organisation, Germans (6.5 million), Ukrainians (1.36 million) and Russians (876 thousand) accounted for the largest groups of foreign tourists (Polish Tourism Organisation 2020). This means that in 2017 over 2 million tourists from Russia and Ukraine arrived in Poland. A more detailed analysis of the number of tourists in this group shows that in recent years their number has either decreased (Russians) or remained unchanged (Ukrainians). According to ROSSTAT data (Federal State Statistics Service 2020), Poland was visited by $11 \%$ fewer Russians in 2018 than in the 
previous year and, according to UKRSTAT, the number remained at a similar level (an increase of $0.1 \%$ ) in the case of Ukrainians (State Statistics Service of Ukraine 2020). This fact can be explained by the economic situation of these countries, the level of earnings of their citizens and the expenditure structure, but also by the perceived destination image of Poland.

Taking these points into account, the purpose of this article is to compare the destination image of Poland as perceived by Russians and Ukrainians.

The following research questions were posed:

What is Poland's perceived destination image among Russians and Ukrainians?

- Does Poland's perceived destination image among Russians differ from the image among Ukrainians?

- Does Poland's perceived destination image among visitors differ from the image among non-visitors?

This study's new contribution to literature is the comparison of the image of Poland perceived by visitors and non-visitors. The lack of literature regarding the image held by non-visitors has been emphasised by many authors (Beerli \& Martin 2004; Cherifi et al. 2014). Focusing on visitors and non-visitors will increase the amount of information on the differences in the images that those who have experienced the destination (visitors) and those who have never been there (non-visitors) hold in their minds, as well as provide data on the extent of these differences. This study will contribute to the understanding of the process of how an image of a destination is shaped.

In addition, the added value of the work is that it is the first study that compares how citizens from two separate countries that until 1991 constituted one state (the Union of Soviet Socialist Republics) perceive a post-socialist country (Poland). This is important because, as research shows, the image that tourists (especially non-visitors) have of a country is often shaped at an early stage of development (in childhood, at school) (Cherifi et al. 2014); this image is extremely durable and changes slowly (Anholt 2003; Pike 2008). It is therefore possible that the opinion of the respondents was shaped in schools that used the same teaching methods and programmes emphasising the leading economic and political role of the USSR in the bloc of socialist countries. The study is also important due to the different pace of development and the paths taken of the three countries studied.

Getting to know the image held by people who have never visited Poland and comparing it with the image held by tourists who have past experience with the destination may be the basis for developing a strategic promotional plan and creating a strong tourist brand (Fakeye \& Crompton 1991).

\section{Literature review - destination image}

Research on the perception and behaviour of consumers is based on the statement of Thomas \&Thomas (1928, as cited in Xesfingi et al. 2018) that 'what people define or perceive has real consequences'. In the 1950s, Boulding (1956) and Martineau (1958) confirmed this by suggesting that human behaviour depends more on the image people create than on objective reality.

The concept of image was quickly introduced to various areas of life, including tourism. The first studies on the image of a tourist destination appeared in the 1970s (Gunn 1972), but at the beginning of the current century, Pike (2002, as cited in Konecnik \& Gartner 2007) referred to 142 studies on the subject.

Most authors believe that image is the core and the driving force of the tourist system. It promotes and motivates purchasing and consumption in a given place (Baloglu \& McCleary 1999; DiazRodriguez et al. 2013).

Currently, there is no single definition in the literature for this concept, which is characteristic of postmodernism (ed. Guba 1990).
A review of the literature shows that the image of a destination is most often defined as 'a set of beliefs, opinions and impressions about a given place (Echtner \& Ritchie 2003), as 'a synthesis of all information from various channels' (Assael 1984) or as 'mental connotations that a person has about a given place' (Baloglu \& McCleary 1999).

Some authors clearly separate the concepts of destination image and destination imagery (Cardoso, Dias et al. 2019, Kuhzady et al. 2017; Araújo et al. 2019; Cardoso, Vila et al. 2019). The destination image includes all mental associations with a particular name of a destination and consists of three dimensions: attributes, advantages and attitude towards the destination (Keller 1993), whereas the destination imagery is a mental process that is responsible for processing and storing multisensory information in the working memory (Echtner \& Ritchie 2003; Cardoso, Dias et al. 2019). As Cardoso, Dias et al. (2019) point out, imagery harmonises with the symbolic and the real, allowing potential tourists to create ideas, histories and visions related to a destination. Even if a person has never visited a particular destination, it is the imagination that drives the perception of this destination in their mind (Cardoso, Dias et al. 2019).

Most authors assume that the image of a destination consists of two main elements: cognitive and affective. The cognitive image is based on the information about the objective features of the place and on the assessment of the attributes of its resources and attractions (Baloglu \& McCleary 1999; De Jesus 2013; Pike \& Ryan 2004). On the other hand, the affective image refers to the feelings or emotions of individuals towards destinations (Kim \& Richardson 2003; Beerli \& Martin 2004; Aksoy \& Kiyci 2011).

The image of a tourist destination depends on many factors Baloglu \& McCleary (1999) suggest that these are based on personal characteristics: psychological (motivations, personality), social (age, education, financial situation), and stimulating factors (sources of information, amount and type of information, past experience). They state that the sources of information (diversity and type) have a significant impact on the cognitive element, and psychological and social features have a greater impact on the emotional element.

Stabler (1988) highlighted the factors of demand and supply Among the factors of demand, the author listed the socio-economic characteristics of tourists, their motivations, perceptions, psychological characteristics, and tourist experiences. As for supply factors, he included education, media and marketing. In the latter case, national tourist organisations (e.g. Polish Tourism Organisation) play a major role in shaping the image of a destination. Stabler's theoretical findings (1988) were confirmed empirically. The importance of gender and age in shaping a destination's image was demonstrated by MacKay \& Smith (2006), and cultural background by Fuchs \& Pikkemaat (2004). Research by Beerli \& Martin (2004) confirmed that the image depends on the tourist's past experiences, their degree of knowledge about the tourist destination, the geographical origin of the tourist, their social and cultural origin, and their expectations of the destination. Fakeye \& Crompton (1991) demonstrated that the image stored by people who had not visited the destination previously is very different from the reality. Cherifi et al. (2014) noticed that the perceptions of non-visitors are often based on comparisons with their own place of residence.

While researching destination imagery, Cardoso, Dias et al. (2019) introduced the terms dream destination and favourite destination. The first term refers to an imaginary place that the tourist has never visited but plans or wants to visit in the future, whereas a favourite destination refers to a place the tourist has already been and perceives as the best for that particular type of travel destination. The authors found significant differences between describing a dream destination and a favourite destination. In 
Table 1. Socio-demographic characteristics of the respondents

\begin{tabular}{|c|c|c|c|c|}
\hline \multirow{2}{*}{ Feature } & \multicolumn{2}{|c|}{ Russians } & \multicolumn{2}{|c|}{ Ukrainians } \\
\hline & number of respondents & percentage & number of respondents & percentage \\
\hline \multicolumn{5}{|c|}{ Gender } \\
\hline Women & 174 & 56.3 & 172 & 54.4 \\
\hline Men & 135 & 43.7 & 144 & 45.6 \\
\hline \multicolumn{5}{|c|}{ Age } \\
\hline Up to 18 years & 40 & 12.9 & 61 & 19.3 \\
\hline 19-40 years & 173 & 56.0 & 176 & 55.7 \\
\hline $41-65$ years & 66 & 21.4 & 41 & 13.0 \\
\hline Over 65 years & 30 & 9.7 & 38 & 12.0 \\
\hline \multicolumn{5}{|c|}{ Place of residence } \\
\hline Village & 40 & 12.9 & 87 & 27.5 \\
\hline City & 170 & 55.0 & 162 & 51.3 \\
\hline Capital city of the region & 99 & 32.1 & 67 & 21.2 \\
\hline \multicolumn{5}{|c|}{ Previously visited Poland } \\
\hline Yes & 73 & 23.6 & 190 & 60.1 \\
\hline No & 236 & 76.4 & 126 & 39.1 \\
\hline
\end{tabular}

Source: own study based on surveys

the first case a psychological evaluation dominates, while in the second a functional assessment is made.

\section{Research methods}

This study focuses on the cognitive element of the image of a destination. The research process included a few stages. In the first, information on Poland's perceived destination image among Russians and Ukrainians was gathered. This was accomplished using a survey. It was assumed that a destination's image is a set of ideas, statements and beliefs about a place, which all result from individual perception. This assumption is in line with many authors' understanding of a destination's image (Lawson \& BaudBovy 1977; Crompton 1979; Gartner \& Hunt 1987). An assumption was also made that the assessment of the 16 statements included in the questionnaire added up to the image of Poland.

The respondents had to assess, among other things, tourist infrastructure, tourist attractions, travel safety, the offer available, and the prices of tourist services in Poland. The selection of the features was based on a literature review (Jarvis et al. 2016; Sukiman et al. 2013; Beerli \& Martin 2004) and a questionnaire prepared by the Polish Tourism Organisation (Satysfakcja turystów [Tourist satisfaction] 2015). The survey used a 5-point Likert scale, where 1 meant complete disagreement with the statement, 3 was neutral, and 5 indicated complete agreement.

Both 5-point and 7-point scales are used in similar studies. The 7-point scale provides a higher accuracy of measurements, but only in reference to single statements. In the case of a larger number of statements, a wider range of scale influences the correct perception of respondents in a negative way. Using a scale that includes too many points can cause flattening, meaning that the respondent groups the individual points and only then answers the question. Although 7-point scales do increase the level of diversity in the answers, they can also force the respondents to choose irrelevant answers that are not in line with their perception of the statement they are rating (Tarka 2015).
Considering the quite wide range of statements (16) included in the survey, a 5-point scale was chosen. This way, the dispersion of answers was limited (Sztabiński 2003).

The research sample was selected using the Convenience Sampling Technique, in which respondents are recruited primarily due to their easy availability. Cherifi et al. (2014) used a similar approach when examining the image of London held by nonvisitors from the Czech Republic. The survey was conducted in June and July 2018 in St Petersburg on a sample of 348 Russian tourists. After verification, 309 completed surveys were accepted for analysis. At the same time, 362 Ukrainian tourists filled in the survey in Kiev and Lviv. In this case, 316 questionnaires were suitable for analysis. The survey was carried out in hotels among tourists from different regions of Russia and Ukraine. The hotels, located in the centre and the outskirts of cities, offered accommodation services mainly to tour groups and individual domestic tourists. People who had been to Poland in the past (visitors) and those who had not (non-visitors) participated in the research. One part of the non-visitors group declared that they would like to visit Poland in the future; the other decided that Poland is not a country that they want to get to know as tourists. Surveys were conducted by the authors of this article and, after prior training, by students of the Faculty of Geography at the Pedagogical University of Herzen in St Petersburg and the Faculty of Geography at the Ivan Franko National University of Lviv. Prior to this, the language of the survey questionnaire had been verified and corrected after pilot studies on a group of 25 Russian and Ukrainian tourists.

The structure of respondents showed that most were women. In the case of Russian tourists, they constituted over $56 \%$ of the sample, and for Ukrainian tourists the figure was over $54 \%$ (Table 1). Among both Russian and Ukrainian respondents, people aged 19 to 40 were the most numerous (approx. $60 \%$ of Russians and Ukrainians surveyed); most of the respondents lived in cities ( $87 \%$ of Russians, $72 \%$ of Ukrainians); and $23 \%$ of 
MISCELLANEA GEOGRAPHICA - REGIONAL STUDIES ON DEVELOPMENT

Vol. $25 \cdot$ No. $3 \cdot 2021 \cdot$ pp. 169-180 •ISSN: 2084-6118 • DOI: 10.2478/mgrsd-2020-0052

Table 2. Cronbach's correlation coefficients and values after omitting a given statement for surveys completed by Russians and Ukrainians

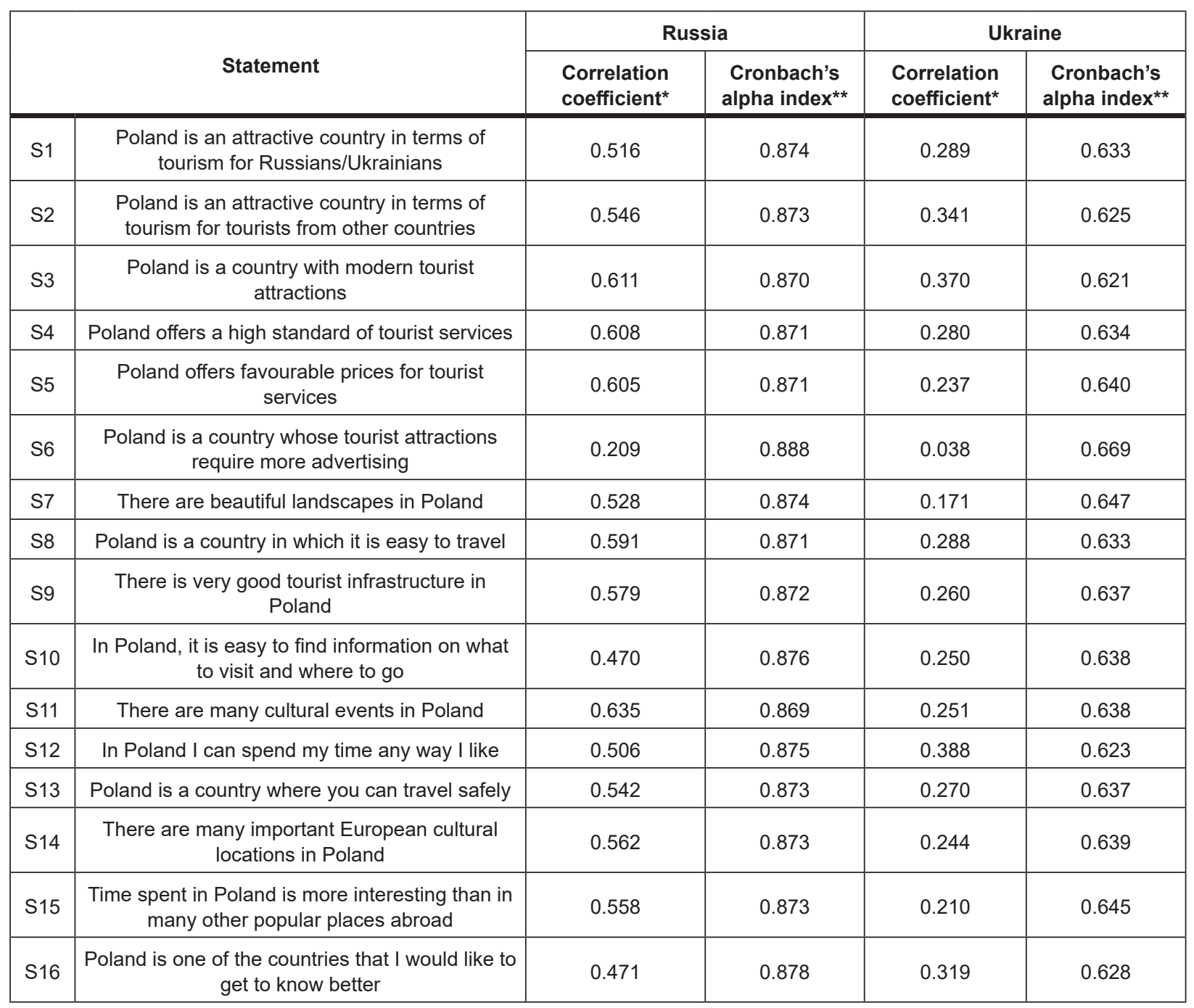

* between a given statement and the total result of the survey calculated after omitting that statement

** assessed after omitting a given statement

Source: own calculations

Russian tourists and just over $60 \%$ of Ukrainian tourists had had a tourist experience that involved a stay in Poland.

In the second stage, the reliability of the survey was verified. This means the stability of the results of the survey, when carried out again on the same group of respondents, was assessed using Cronbach's alpha index. This index records values from 0 to 1 , where values close to 1 indicate the high reliability of the survey. The lowest acceptable value for a reliable survey is 0.6 (Hair et al. 1998). Cronbach's alpha index was determined separately for questionnaires completed by Russians and Ukrainians. In the first case it was close to 0.9; in the second it was higher than 0.6.

The correlation coefficients were calculated to verify the utility and correctness of how the statements were formed. The average correlation coefficients between pairs of individual statements in the questionnaire for Russian respondents was much higher than for Ukrainian respondents (0.329 vs 0.109$)$. In addition, the individual statements in the questionnaire were characterised by different values of the correlation coefficient between a given statement and the total summary result of the survey calculated after omitting the given statement (Table 2). For each statement, the correlation coefficients were much higher for respondents from Russia than for those from Ukraine. The statement that correlated the least with the total summary result of the survey was S6; this concerned surveys completed both by Russians and Ukrainians. Additionally, it was noted that the removal of the S6 statement resulted in the largest increase in Cronbach's alpha index for both groups of respondents. As a result, S6 was excluded from the analysis as it was considered to have not been very clearly worded. The statements that correlated best with the total summary result of the survey were S11 for Russians and S12 for Ukrainians.

The surveys carried out can therefore be considered reliable. The research results were presented as a percentage summary comparing the variation of answers in individual groups of respondents (Russians, Ukrainians, visitors, non-visitors). 
The description of the study results also uses the mean and the standard deviation.

In the next stage, the perceived destination image of Poland as created by Russians and Ukrainians was determined. The assumption was made that this image was formed from the ratings of the 15 statements included in the questionnaire (Table 2). That is why individual statements were examined to determine whether they had been assessed positively (respondents strongly agree or somewhat agree with an individual statement) or negatively (respondents strongly disagree or somewhat disagree with an individual statement). The research procedure included the verification of parametric null hypotheses, which showed that Poland's perceived destination image, as described by the 15 statements, was neutral (its value was 3 on the Likert scale). As a result, the null hypotheses took the form of:

$H_{0}: m=3$

Next, the alternative hypotheses were introduced:

$H_{1}: m>3$

Student's t-test was used to verify the null hypotheses. With the level of significance at 0.05 and the appropriate number of degrees of freedom $-v(v=n-1$ where: $n$ equals sample size $)$, the verifying decision could have been made:

- if the empirical value of Student's t-test is within the area of critical values to reject the null hypothesis $\left(H_{0}\right)$ and accept the alternative hypothesis $\left(H_{1}\right)$, Poland's perceived destination image was considered positive in reference to the individual statements

or it could be stated:

- there is no basis for rejecting the null hypothesis $\left(H_{0}\right)$ if the empirical value of Student's t-test exceeds the critical values range. As a result Poland's perceived destination image could not be considered as positive in reference to individual statements.

An assumption was made that if at least a half (8) of the statements are positively assessed by the respondents, the perceived destination image of Poland, understood as a set of ideas, will be positive. Otherwise, the whole image should be assessed as negative. This research process was also used to determine the image created by visitors and non-visitors. The Pearson correlation coefficient was used to compare the image held by the groups of respondents (Russians and Ukrainians, visitors and non-visitors).

\section{Research results}

The result of the conducted verification procedures of the null hypotheses indicates that both Russians and Ukrainians perceived 14 out of 15 elements of Poland's destination image as positive (Table 3 ). They only disagreed with the statement (S15) that: Time spent in Poland is more interesting than in many other popular places abroad. This means that the general image of Poland created by the respondents of the nations researched is positive.

In addition, the calculated Pearson correlation coefficient, which is 0.85 , proves that Poland's perceived destination image from the perspective of Russians does not differ significantly from that held by Ukrainians.

Slight differences between Russians and Ukrainians occurred with regard to the mean values on the Likert scale and the percentage share of positive (strongly agree and somewhat agree) and negative (strongly disagree and somewhat disagree) answers when assessing the individual elements of
Table 3. Results of the null hypotheses verification in reference to Russians and Ukrainians

\begin{tabular}{|c|c|c|}
\hline \multirow{2}{*}{ Statement } & Russians & Ukrainians \\
\cline { 2 - 3 } & \multicolumn{2}{|c|}{ Empirical value of t-test } \\
\cline { 2 - 3 } & level of significance - 0.05; m = cv = 1.96 \\
\hline S1 & 10.85 & 6.93 \\
\hline S2 & 8.71 & 6.06 \\
\hline S3 & 7.26 & 10.10 \\
\hline S4 & 9.70 & 11.16 \\
\hline S5 & 6.46 & 9.42 \\
\hline S7 & 22.92 & 25.17 \\
\hline S8 & 14.38 & 14.77 \\
\hline S9 & 11.37 & 14.02 \\
\hline S10 & 17.20 & 14.68 \\
\hline S11 & 14.94 & 18.19 \\
\hline S12 & 22.04 & 20.29 \\
\hline S13 & 12.28 & 21.46 \\
\hline S14 & 18.82 & 14.00 \\
\hline S15 & 0.36 & 1.72 \\
\hline S16 & 14.05 & 11.02 \\
\hline
\end{tabular}

$m-H_{0}$

$c v$ - critical value according to tables of Student's t distribution Source: own study based on surveys

Poland's image. In all cases, ratings of the individual statements were higher than neutral (3) on the Likert scale. In the case of Russians they varied from 3.02 (S15) to 4.16 (S7) and in the case of Ukrainians from 3.10 (S15) to 4.14 (S7) (Table 4).

Russians made a slightly higher assessment for statements S1, S2, S12, S14 and S16, and Ukrainians for S3, S4, S5 and $\mathrm{S} 13$. In the case of the other statements, almost identical average values on the Likert scale were noted. However, the differences were slight and did not exceed the value of standard deviation (Table 4).

Respondents of both nations rated the natural attractions of Poland the highest - beautiful landscapes (S7). A different study conducted by the authors of this paper (not published yet) shows that both Russians and Ukrainians appreciate the landscape of Polish lake districts as well as Tatra and Bieszczady National Parks.

Additionally, Russians rated statements S12 and S16 (In Poland I can spend my time any way I like; Poland is one of the countries that I would like to get to know better) highly (more than 4 points). It should be stressed that for Russians Poland is part of the West, which is a rather attractive place to spend free time. Considering the fact that less than $25 \%$ of respondents from Russia had been to Poland in the past, it can be stated that Poland is, in fact, a dream destination for them. In the case of Ukrainians, Poland is also part of the West but, in practice, Ukrainian tourists have more opportunities to verify the particular statements regarding Poland's image, which lowered their ratings.

It is worth noting that Ukrainians gave a higher rating to those elements of image that would be considered functional 
MISCELLANEA GEOGRAPHICA - REGIONAL STUDIES ON DEVELOPMENT

Vol. $25 \cdot$ No. $3 \cdot 2021 \cdot$ pp. 169-180 • ISSN: 2084-6118 • DOI: 10.2478/mgrsd-2020-0052

Table 4. Summary comparing the variation of Russian and Ukrainian answers

\begin{tabular}{|c|c|c|c|c|c|c|c|}
\hline \multicolumn{6}{|c|}{ Do you agree with the following statements (data in \%) } & \multicolumn{2}{|c|}{ measures } \\
\hline category & $\begin{array}{l}\text { strongly } \\
\text { disagree }\end{array}$ & $\begin{array}{c}\text { somewhat } \\
\text { disagree }\end{array}$ & $\begin{array}{c}\text { neither agree } \\
\text { nor disagree }\end{array}$ & $\begin{array}{c}\text { somewhat } \\
\text { agree }\end{array}$ & $\begin{array}{l}\text { strongly } \\
\text { agree }\end{array}$ & mean & $\begin{array}{l}\text { standard } \\
\text { deviation }\end{array}$ \\
\hline \multicolumn{8}{|c|}{ S1. Poland is an attractive country in terms of tourism for Russians/Ukrainians } \\
\hline Russians & 2.9 & 4.9 & 41.7 & 32.4 & 18.1 & 3.58 & 0.94 \\
\hline Ukrainians & 7.3 & 11.4 & 31.0 & 29.7 & 20.6 & 3.45 & 1.15 \\
\hline \multicolumn{8}{|c|}{ S2. Poland is an attractive country in terms of tourism for tourists from other countries } \\
\hline Russians & 2.3 & 11.3 & 40.1 & 27.2 & 19.1 & 3.50 & 1.00 \\
\hline Ukrainians & 1.3 & 22.8 & 28.8 & 34.8 & 12.3 & 3.34 & 1.00 \\
\hline \multicolumn{8}{|c|}{ S3. Poland is a country with modern tourist attractions } \\
\hline Russians & 1.9 & 16.2 & 34.0 & 36.2 & 11.7 & 3.39 & 0.96 \\
\hline Ukrainians & 0.9 & 12.0 & 38.6 & 26.6 & 21.8 & 3.56 & 0.99 \\
\hline \multicolumn{8}{|c|}{ S4. Poland offers a high standard of tourist services } \\
\hline Russians & 0.6 & 9.1 & 45.0 & 34.6 & 10.7 & 3.46 & 0.83 \\
\hline Ukrainians & 3.8 & 6.6 & 32.6 & 37.0 & 19.9 & 3.63 & 1.00 \\
\hline \multicolumn{8}{|c|}{ S5. Poland offers favourable prices for tourist services } \\
\hline Russians & 4.5 & 9.4 & 43.4 & 32.0 & 10.7 & 3.35 & 0.95 \\
\hline Ukrainians & 3.5 & 9.5 & 37.0 & 28.5 & 21.5 & 3.55 & 1.04 \\
\hline \multicolumn{8}{|c|}{ S7. There are beautiful landscapes in Poland } \\
\hline Russians & 0.0 & 4.5 & 19.1 & 32.4 & 44.0 & 4.16 & 0.89 \\
\hline Ukrainians & 0.3 & 1.9 & 18.7 & 41.8 & 37.3 & 4.14 & 0.80 \\
\hline \multicolumn{8}{|c|}{ S8. Poland is a country in which it is easy to travel } \\
\hline Russians & 1.6 & 4.9 & 33.7 & 35.6 & 24.3 & 3.76 & 0.93 \\
\hline Ukrainians & 0.9 & 3.5 & 39.9 & 31.6 & 24.1 & 3.74 & 0.89 \\
\hline \multicolumn{8}{|c|}{ S9. There is very good tourist infrastructure in Poland } \\
\hline Russians & 1.0 & 8.7 & 36.9 & 40.5 & 12.9 & 3.56 & 0.86 \\
\hline Ukrainians & 0.3 & 8.9 & 29.1 & 48.4 & 13.3 & 3.66 & 0.83 \\
\hline \multicolumn{8}{|c|}{ S10. In Poland, it is easy to find information on what to visit and where to go } \\
\hline Russians & 0.0 & 4.5 & 31.7 & 43.0 & 20.7 & 3.80 & 0.82 \\
\hline Ukrainians & 1.6 & 2.8 & 38.3 & 34.8 & 22.5 & 3.74 & 0.89 \\
\hline \multicolumn{8}{|c|}{ S11. There are many cultural events in Poland } \\
\hline Russians & 1.0 & 7.4 & 27.8 & 38.5 & 25.2 & 3.80 & 0.94 \\
\hline Ukrainians & 0.3 & 4.4 & 27.5 & 47.5 & 20.3 & 3.83 & 0.81 \\
\hline \multicolumn{8}{|c|}{ S12. In Poland I can spend my time any way I like } \\
\hline Russians & 0.0 & 3.6 & 22.0 & 39.8 & 34.6 & 4.06 & 0.84 \\
\hline Ukrainians & 0.6 & 3.2 & 23.1 & 53.2 & 19.9 & 3.89 & 0.78 \\
\hline \multicolumn{8}{|c|}{ S13. Poland is a country where you can travel safely } \\
\hline Russians & 1.3 & 10.4 & 28.8 & 39.5 & 20.1 & 3.67 & 0.95 \\
\hline Ukrainians & 0.0 & 2.5 & 25.9 & 57.9 & 13.6 & 3.83 & 0.68 \\
\hline \multicolumn{8}{|c|}{ S14. There are many important European cultural locations in Poland } \\
\hline Russians & 0.6 & 4.2 & 24.6 & 43.7 & 26.9 & 3.92 & 0.86 \\
\hline Ukrainians & 0.3 & 7.6 & 35.4 & 31.6 & 25.0 & 3.73 & 0.93 \\
\hline \multicolumn{8}{|c|}{ S15. Time spent in Poland is more interesting than in many other popular places abroad } \\
\hline Russians & 8.7 & 24.9 & 31.7 & 24.6 & 10.0 & 3.02 & 1.12 \\
\hline Ukrainians & 5.7 & 20.6 & 44.0 & 17.4 & 12.3 & 3.10 & 1.05 \\
\hline \multicolumn{8}{|c|}{ S16. Poland is one of the countries that I would like to get to know better } \\
\hline Russians & 7.4 & 6.8 & 13.3 & 23.0 & 49.5 & 4.00 & 1.25 \\
\hline Ukrainians & 3.5 & 10.8 & 26.3 & 35.1 & 24.4 & 3.66 & 1.07 \\
\hline
\end{tabular}

Source: own study based on surveys 
(Cardoso, Dias et al. 2019), meaning those that would have required a previous visit to Poland, for example the standard and prices of tourist services, safety while travelling and the quality of the tourist offer. Russians, on the other hand, had a better perception of Poland's image in the scope of more general, psychological statements, for example In Poland I can spend my time any way I like; Poland is an attractive country, etc. In accordance with the suggestions of Cardoso, Dias et al. (2019), such ratings are connected to the past tourist experience of respondents. Those tourists who had previously stayed in a particular tourist destination and know it from their own experience (visitors) use functional statements more often to assess it. Often, it is their favourite destination. In contrast, in the case of non-visitors, the assessments point more to psychological aspects (dreams, ideas), which is a characteristic of perceiving a dream destination. Among the respondents, only one in four Russians declared that they had visited Poland in the past, whereas among Ukrainians those who had previously visited accounted for $60 \%$.

An analysis of the percentage share of positive (somewhat agree and strongly agree) and negative (somewhat disagree and strongly disagree) answers provides more information on the differences held by Russians and Ukrainians concerning Poland's image.

For example, in the case of statements S4, S5 and S9, Ukrainians had a slightly better perception of the attractiveness of Poland as a tourist destination than Russians (Table 4). These statements describe the quality and prices of services and tourist accommodation - characteristic that are the easiest to assess during a direct visit to Poland. Such a high rating given by Ukrainian respondents was probably influenced by the quality of roads and the diversity of accommodation facilities offered in Poland. As research shows, tourists often create the destination's image by comparing individual elements with their own place of living (Cherifi et al. 2014). Following EU accession, Poland used EU funds to strongly improve all elements of the tourist infrastructure, so in comparison to the infrastructure in Ukraine, this must have benefited Poland.

Moreover, more Ukrainian (approx. 72\%) than Russian (less than $60 \%$ ) respondents agreed with the statement that Poland is a country where you can travel safely (S13) (Table 4). Such a high rating by Ukrainians could result from the possibility to personally assess the level of safety while travelling across Poland. Previous positive experiences in this regard influenced the final opinion (Fuchs \& Reichel 2006).

In the case of statements S8, S10 and S16 the share of positive ratings was slightly higher among Russians than Ukrainians (Table 4). A stronger support for these statements from Russians could result from the fact that Poles know the Russian language better than Ukrainian. Russian respondents were aware of the fact that learning their language was obligatory at all stages of education in all states of the Eastern Bloc.

Russians also better perceive the concentration of important sites of European culture in Poland (S14) than Ukrainians. More than $70 \%$ of Russian respondents agreed with the statement. In the case of Ukrainians, this group accounted for less than $57 \%$. Ukrainians had had a better opportunity to verify the thesis in this statement, so they were less enthusiastic about it.

From a cognitive point of view, the declarations regarding the statement S15 Time spent in Poland is more interesting than in many other popular places abroad were interesting. One in three of the surveyed citizens of Ukraine and Russia agreed with this statement, but roughly the same number of respondents did not. This aspect of Poland's perceived destination image was not verified in a positive way. This means that Poland as a destination is perceived positively by Russians and Ukrainians but, in general, they prefer spending their free time in other
Table 5. The results of verification of null hypotheses in relation to Russian and Ukrainian visitors and non-visitors

\begin{tabular}{|c|c|c|c|c|}
\hline \multirow{2}{*}{\begin{tabular}{c}
\multirow{2}{*}{ state- } \\
ments
\end{tabular}} & $\begin{array}{c}\text { Russians }- \\
\text { visitors }\end{array}$ & $\begin{array}{c}\text { Russians - } \\
\text { non-visitors }\end{array}$ & $\begin{array}{c}\text { Ukrainians - } \\
\text { visitors }\end{array}$ & $\begin{array}{l}\text { Ukrainians - } \\
\text { non-visitors }\end{array}$ \\
\cline { 2 - 5 } & $c v=\mathbf{2 . 0 0}$ & $c v=\mathbf{1 . 9 6}$ & $c v=\mathbf{1 . 9 6}$ & $c v=\mathbf{1 . 9 8}$ \\
\cline { 2 - 5 } & \multicolumn{4}{|c|}{ empirical value of Student's t-test } \\
\hline S1 & 5.75 & 9.18 & 6.01 & 3.59 \\
\hline S2 & 5.09 & 7.14 & 4.65 & 3.88 \\
\hline S3 & 3.89 & 6.07 & 7.99 & 6.15 \\
\hline S4 & 6.24 & 7.67 & 8.47 & 7.24 \\
\hline S5 & 4.46 & 5.06 & 7.84 & 5.34 \\
\hline S7 & 12.16 & 19.37 & 19.93 & 15.38 \\
\hline S8 & 10.85 & 10.92 & 12.55 & 8.06 \\
\hline S9 & 6.58 & 9.35 & 12.79 & 6.93 \\
\hline S10 & 8.04 & 15.31 & 11.13 & 9.59 \\
\hline S11 & 6.92 & 13.15 & 13.42 & 12.37 \\
\hline S12 & 9.82 & 19.93 & 16.96 & 11.55 \\
\hline S13 & 6.28 & 10.48 & 15.77 & 14.68 \\
\hline S14 & 12.40 & 14.98 & 10.75 & 8.95 \\
\hline S15 & $\mathbf{1 . 6 8}$ & $-\mathbf{0 . 5 3}$ & $\mathbf{0 . 6 8}$ & $\mathbf{1 . 9 2}$ \\
\hline S16 & 5.80 & 12.76 & 7.79 & 7.86 \\
\hline & & & & \\
\hline
\end{tabular}

$c v$ - critical value according to tables of Student's $t$ distribution Source: own study based on surveys

places. Possible reasons for this are the rather unstable weather, the rainy summer and the lack of a warm, salty sea - attributes that determine the quality of the holiday in mass tourism.

Beerli and Martin (2004) stated that the image of a tourist destination depends on the tourist's past experience, among other things. This raises the question as to whether the perceived destination image of Poland, from the perspective of Russians and Ukrainians, is influenced by visits to our country in the past.

The results of the conducted procedures to verify null hypotheses indicate that both Russian and Ukrainian visitors and non-visitors rated 14 out of 15 elements of Poland's perceived destination image positively (Table 5).

The calculated Pearson correlation coefficient shows that the perceived destination image of Poland did not differ significantly between Russian and Ukrainian visitors and non-visitors (Pearson correlation coefficient: Russia 0.886, Ukraine 0.896).

For both Russians and Ukrainians, the differences between the mean values on the Likert scale related to individual statements, and the differences in the structure of the positive and negative responses were minor. The ratings of the individual statements were higher than the neutral value on the Likert scale, except for Russian non-visitor ratings of statement S15 (Time spent in Poland is more interesting than in many other popular places abroad). In this case, the average value on the Likert scale was 2.96. Other ratings of Russian non-visitors ranged from 3.32 to 4.15 , whereas those of Russian visitors from 3.22 to 4.18. These ranges for Ukrainian visitors were between 3.05 and 4.13 , while for non-visitors they ranged between 3.17 and 4.15 (Table 6).

Comparing the average values on the Likert scale for all statements, both for Russian and Ukrainian visitors and non- 
MISCELLANEA GEOGRAPHICA - REGIONAL STUDIES ON DEVELOPMENT

Vol. $25 \cdot$ No. $3 \cdot 2021 \cdot$ pp. 169-180 • ISSN: 2084-6118 • DOI: 10.2478/mgrsd-2020-0052

Table 6. Summary comparing the variation of visitor and non-visitor answers

\begin{tabular}{|c|c|c|c|c|c|c|c|}
\hline \multicolumn{6}{|c|}{ Do you agree with the following statements (data in \%) } & \multicolumn{2}{|c|}{ measures } \\
\hline category & $\begin{array}{l}\text { strongly } \\
\text { disagree }\end{array}$ & $\begin{array}{c}\text { somewhat } \\
\text { disagree }\end{array}$ & $\begin{array}{c}\text { neither agree } \\
\text { nor disagree }\end{array}$ & $\begin{array}{l}\text { somewhat } \\
\text { agree }\end{array}$ & $\begin{array}{l}\text { strongly } \\
\text { agree }\end{array}$ & mean & $\begin{array}{l}\text { standard } \\
\text { deviation }\end{array}$ \\
\hline \multicolumn{8}{|c|}{ S1. Poland is an attractive country in terms of tourism for Russians/Ukrainians } \\
\hline Russians - visitors & 0.0 & 6.8 & 45.2 & 31.5 & 16.4 & 3.58 & 0.85 \\
\hline Russians - non-visitors & 3.8 & 4.2 & 40.7 & 32.6 & 18.6 & 3.58 & 0.97 \\
\hline Ukrainians - visitors & 5.8 & 12.6 & 31.1 & 26.3 & 24.2 & 3.51 & 1.16 \\
\hline Ukrainians - non-visitors & 9.5 & 9.5 & 31.0 & 34.9 & 15.1 & 3.37 & 1.14 \\
\hline \multicolumn{8}{|c|}{ S2. Poland is an attractive country in terms of tourism for tourists from other countries } \\
\hline Russians - visitors & 0.0 & 11.0 & 41.1 & 30.1 & 17.8 & 3.55 & 0.91 \\
\hline Russians - non-visitors & 3.0 & 11.4 & 39.8 & 26.3 & 19.5 & 3.48 & 1.03 \\
\hline Ukrainians - visitors & 0.5 & 22.6 & 31.1 & 35.8 & 10.0 & 3.32 & 0.95 \\
\hline Ukrainians - non-visitors & 2.4 & 23.0 & 25.4 & 33.3 & 15.9 & 3.37 & 1.08 \\
\hline \multicolumn{8}{|c|}{ S3. Poland is a country with modern tourist attractions } \\
\hline Russians - visitors & 0.0 & 23.3 & 21.9 & 39.7 & 15.1 & 3.47 & 1.01 \\
\hline Russians - non-visitors & 2.5 & 14.0 & 37.7 & 35.2 & 10.6 & 3.37 & 0.94 \\
\hline Ukrainians - visitors & 1.1 & 11.6 & 38.4 & 26.3 & 22.6 & 3.58 & 1.00 \\
\hline Ukrainians - non-visitors & 0.8 & 12.7 & 38.9 & 27.0 & 20.6 & 3.54 & 0.99 \\
\hline \multicolumn{8}{|c|}{ S4. Poland offers a high standard of tourist services } \\
\hline Russians - visitors & 0.0 & 8.2 & 35.6 & 47.9 & 8.2 & 3.56 & 0.76 \\
\hline Russians - non-visitors & 0.8 & 9.3 & 47.9 & 30.5 & 11.4 & 3.42 & 0.85 \\
\hline Ukrainians - visitors & 3.2 & 7.9 & 33.2 & 36.8 & 18.9 & 3.61 & 0.99 \\
\hline Ukrainians - non-visitors & 4.8 & 4.8 & 31.7 & 37.3 & 21.4 & 3.66 & 1.02 \\
\hline \multicolumn{8}{|c|}{ S5. Poland offers favourable prices for tourist services } \\
\hline Russians - visitors & 0.0 & 12.3 & 41.1 & 37.0 & 9.6 & 3.44 & 0.83 \\
\hline Russians - non-visitors & 5.9 & 8.5 & 44.1 & 30.5 & 11.0 & 3.32 & 0.98 \\
\hline Ukrainians - visitors & 2.6 & 8.9 & 37.9 & 30.0 & 20.5 & 3.57 & 1.00 \\
\hline Ukrainians - non-visitors & 4.8 & 10.3 & 35.7 & 26.2 & 23.0 & 3.52 & 1.10 \\
\hline \multicolumn{8}{|c|}{ S7. There are beautiful landscapes in Poland } \\
\hline Russians - visitors & 0.0 & 4.1 & 13.7 & 42.5 & 39.7 & 4.18 & 0.82 \\
\hline Russians - non-visitors & 0.0 & 4.7 & 20.8 & 29.2 & 45.3 & 4.15 & 0.91 \\
\hline Ukrainians - visitors & 0.0 & 2.1 & 18.4 & 43.7 & 35.8 & 4.13 & 0.78 \\
\hline Ukrainians - non-visitors & 0.8 & 1.6 & 19.0 & 38.9 & 39.7 & 4.15 & 0.84 \\
\hline \multicolumn{8}{|c|}{ S8. Poland is a country in which it is easy to travel } \\
\hline Russians - visitors & 0.0 & 2.7 & 21.9 & 47.9 & 27.4 & 4.00 & 0.78 \\
\hline Russians - non-visitors & 2.1 & 5.5 & 37.3 & 31.8 & 23.3 & 3.69 & 0.96 \\
\hline Ukrainians - visitors & 0.5 & 3.2 & 37.9 & 32.1 & 26.3 & 3.81 & 0.88 \\
\hline Ukrainians - non-visitors & 1.6 & 4.0 & 42.9 & 31.0 & 20.6 & 3.65 & 0.91 \\
\hline \multicolumn{8}{|c|}{ S9. There is very good tourist infrastructure in Poland } \\
\hline Russians - visitors & 0.0 & 6.8 & 37.0 & 45.2 & 11.0 & 3.60 & 0.78 \\
\hline Russians - non-visitors & 1.3 & 9.3 & 36.9 & 39.0 & 13.6 & 3.54 & 0.89 \\
\hline Ukrainians - visitors & 0.0 & 6.3 & 28.9 & 51.1 & 13.7 & 3.72 & 0.78 \\
\hline Ukrainians - non-visitors & 0.8 & 12.7 & 29.4 & 44.4 & 12.7 & 3.56 & 0.90 \\
\hline \multicolumn{8}{|c|}{ S10. In Poland, it is easy to find information on what to visit and where to go } \\
\hline Russians - visitors & 0.0 & 2.7 & 38.4 & 47.9 & 11.0 & 3.67 & 0.71 \\
\hline Russians - non-visitors & 0.0 & 5.1 & 29.7 & 41.5 & 23.7 & 3.84 & 0.84 \\
\hline
\end{tabular}


Continued Table 6. Summary comparing the variation of visitor and non-visitor answers

\begin{tabular}{|c|c|c|c|c|c|c|c|}
\hline \multicolumn{6}{|c|}{ Do you agree with the following statements (data in \%) } & \multicolumn{2}{|c|}{ measures } \\
\hline category & $\begin{array}{l}\text { strongly } \\
\text { disagree }\end{array}$ & $\begin{array}{l}\text { somewhat } \\
\text { disagree }\end{array}$ & $\begin{array}{c}\text { neither agree } \\
\text { nor disagree }\end{array}$ & $\begin{array}{l}\text { somewhat } \\
\text { agree }\end{array}$ & $\begin{array}{l}\text { strongly } \\
\text { agree }\end{array}$ & mean & $\begin{array}{l}\text { standard } \\
\text { deviation }\end{array}$ \\
\hline Ukrainians - visitors & 2.1 & 2.6 & 37.9 & 33.2 & 24.2 & 3.75 & 0.93 \\
\hline Ukrainians - non-visitors & 0.8 & 3.2 & 38.9 & 37.3 & 19.8 & 3.72 & 0.85 \\
\hline \multicolumn{8}{|c|}{ S11. There are many cultural events in Poland } \\
\hline Russians - visitors & 0.0 & 9.6 & 27.4 & 45.2 & 17.8 & 3.71 & 0.87 \\
\hline Russians - non-visitors & 1.3 & 6.8 & 28.0 & 36.4 & 27.5 & 3.82 & 0.96 \\
\hline Ukrainians - visitors & 0.5 & 3.2 & 32.6 & 46.3 & 17.4 & 3.77 & 0.79 \\
\hline Ukrainians - non-visitors & 0.0 & 6.3 & 19.8 & 49.2 & 24.6 & 3.92 & 0.84 \\
\hline \multicolumn{8}{|c|}{ S12. In Poland I can spend my time any way I like } \\
\hline Russians - visitors & 0.0 & 4.1 & 23.3 & 47.9 & 24.7 & 3.93 & 0.80 \\
\hline Russians - non-visitors & 0.0 & 3.4 & 21.6 & 37.3 & 37.7 & 4.09 & 0.84 \\
\hline Ukrainians - visitors & 0.0 & 3.2 & 22.6 & 55.8 & 18.4 & 3.89 & 0.73 \\
\hline Ukrainians - non-visitors & 1.6 & 3.2 & 23.8 & 49.2 & 22.2 & 3.87 & 0.85 \\
\hline \multicolumn{8}{|c|}{ S13. Poland is a country where you can travel safely } \\
\hline Russians - visitors & 0.0 & 12.3 & 26.0 & 42.5 & 19.2 & 3.68 & 0.93 \\
\hline Russians - non-visitors & 1.7 & 9.7 & 29.7 & 38.6 & 20.3 & 3.66 & 0.97 \\
\hline Ukrainians - visitors & 0.0 & 3.7 & 25.3 & 58.4 & 12.6 & 3.80 & 0.70 \\
\hline Ukrainians - non-visitors & 0.0 & 0.8 & 27.0 & 57.1 & 15.1 & 3.73 & 0.92 \\
\hline \multicolumn{8}{|c|}{ S14. There are many important European cultural locations in Poland } \\
\hline Russians - visitors & 0.0 & 2.7 & 15.1 & 53.4 & 28.8 & 4.08 & 0.74 \\
\hline Russians - non-visitors & 0.8 & 4.7 & 27.5 & 40.7 & 26.3 & 3.87 & 0.89 \\
\hline Ukrainians - visitors & 0.5 & 8.4 & 32.6 & 33.7 & 24.7 & 3.74 & 0.95 \\
\hline Ukrainians - non-visitors & 0.0 & 6.3 & 39.7 & 28.6 & 25.4 & 3.87 & 0.66 \\
\hline \multicolumn{8}{|c|}{ S15. Time spent in Poland is more interesting than in many other popular places abroad } \\
\hline Russians - visitors & 0.0 & 34.2 & 27.4 & 20.5 & 17.8 & 3.22 & 1.11 \\
\hline Russians - non-visitors & 11.4 & 22.0 & 33.1 & 25.8 & 7.6 & 2.96 & 1.11 \\
\hline Ukrainians - visitors & 6.8 & 21.1 & 44.2 & 15.8 & 12.1 & 3.05 & 1.06 \\
\hline Ukrainians - non-visitors & 4.0 & 19.8 & 43.7 & 19.8 & 12.7 & 3.17 & 1.02 \\
\hline \multicolumn{8}{|c|}{ S16. Poland is one of the countries that I would like to get to know better } \\
\hline Russians - visitors & 4.1 & 15.1 & 15.1 & 23.3 & 42.5 & 3.85 & 1.24 \\
\hline Russians - non-visitors & 8.5 & 4.2 & 12.7 & 22.9 & 51.7 & 4.05 & 1.26 \\
\hline Ukrainians - visitors & 2.6 & 12.6 & 28.4 & 36.8 & 19.5 & 3.58 & 1.02 \\
\hline Ukrainians - non-visitors & 4.8 & 7.9 & 23.0 & 32.5 & 31.7 & 3.79 & 1.12 \\
\hline
\end{tabular}

Source: own study based on surveys

visitors, no significant differences in perceiving Poland as a tourist destination were noted. The surveyed Russian visitors perceived Poland's destination image only slightly better than the non-visitors (the mean for all statements on the Likert scale was 3.70 and 3.65 , respectively). The most substantial differences, however, occurred only in the case of two statements - S8 and $\mathrm{S} 14$ - although these are still lower than the standard deviation in the perceived destination image of Poland between Russian visitors and non-visitors. The visitors group of respondents from Russia rated the possibility to travel across Poland better than the non-visitors (S8). They also stated, more often than Russian non-visitors, that There are many important European cultural locations in Poland (S14) (Table 6).
The differences between Ukrainian visitors and non-visitors were even less significant. Contrary to Russians, the non-visitors had a slightly higher mean value for all statements on the Likert scale (3.66) than the visitors (3.64). In the case of Ukrainian visitors and non-visitors, the most substantial difference between the average values on the Likert scale, although still lower than the value of standard deviation, occurred in statement S16 (Table 6). Similar to Russians, Ukrainian non-visitors agreed slightly more often than visitors that Poland is a country that they would like to know better.

Taking into account the percentage share of positive and negative answers, it can be noted that for the majority of statements (10 of 15) a greater number of Russian visitors 
than non-visitors show a positive attitude towards Poland as a tourist destination. However, the difference amounted to more than 10 percentage points for statements S4, S8 and S14 only. The experience gained during a stay in Poland resulted in a positive rating of the standard of tourist services (S4), the ease of travelling across Poland (S8) and the number of important sites for European culture (S14) by a higher percentage of Russian visitors than non-visitors (Table 6).

Similarly, for the majority of statements (9 out of 15$)$ more Ukrainian visitors than non-visitors show a positive attitude towards Poland as a tourist destination. Nevertheless, the differences in the percentage shares of respondents giving positive and negative opinions were unsubstantial (Table 6). Only in the case of statement S11 was the disparity higher than 10 percentage points. More Ukrainian non-visitors than visitors claimed that There are many cultural events in Poland.

The analysis of the percentage share of positive and negative answers of the respondents does not support the statement that a past visitor experience, both by Russians and Ukrainians, changes their perception of Poland's destination image significantly.

\section{Summary and conclusions}

A general conclusion can be made that the citizens of Russia and Ukraine who were surveyed perceived Poland as an attractive tourist destination. This is demonstrated by the values on the Likert scale that reach beyond the neutral point. Poland's natural attractions and tourist infrastructure were rated the highest, whereas the possibility to spend free time in their favourite way was rated the lowest.

There were no major differences in the perceived destination image of Poland between Russians and Ukrainians. The difference in the mean values on the Likert scale was insignificant - only 0.02 - and the correlation coefficient amounted to 0.85 . The high similarity between Russian and Ukrainian responses may indicate that there were some common factors affecting Poland's perceived destination image. Historical determinants, especially from the period of the USSR, seem to be an important factor. Perhaps the school education at that time, using the same core curriculum, was one of the factors that shaped the original image; and the current propaganda in the media, especially on public television, has strengthened this image.

The research shows that in spite of the absence of major differences in the image held by tourists of the surveyed nations, Ukrainians rated the functional elements (prices and standard of tourist services, the safety of travel) slightly higher and Russians the psychological ones (tourist attractiveness of Poland). On the one hand, this may be evidence that a visit to Poland allows a prior opinion to be verified for a particular tourist destination (Cardoso, Dias et al. 2019); on the other, the differences between the image held by visitors and non-visitors were minor. It is possible that visitors' assessments passed on to their family and friends influence the perceived destination image of Poland. Non-visitors accept word-of-mouth ratings and they create an image of Poland based on that

The past experience of the surveyed Russians and Ukrainians had no impact on Poland's perceived destination image. Therefore, the thesis that past experience influences the perception of the destination has not been confirmed (Beerli \& Martin 2004). This means that other factors influenced the perceived destination image of Poland among both Russians and Ukrainians. As other studies show, this is a situation that rarely occurs among the participants of the international tourist movement. Commonly, the experience gained during a trip significantly modifies the image of selected tourist destinations. In the case of the image of Poland held by Ukrainian and Russian tourists, this cannot be stated.

The results of the above study should influence the marketing strategies of the institutions in charge of promoting Poland as a tourist destination in the researched countries. As Poland's image is similar among Russians and Ukrainians, the marketing activities do not have to differ significantly for each nationality. As the majority of those surveyed rated the natural elements of Poland the highest, marketing of Poland should concentrate on elements that are not related to nature. For Russian citizens, advertising should focus on functional elements (attractiveness of prices and standard of tourist services, safety of travel) and, among Ukrainians, the psychological elements should be stressed (friendly atmosphere, attractiveness of sites). Research shows that Russian and Ukrainian knowledge of cultural events in Poland is limited, so marketing campaigns should also consider these elements. Moreover, advertising campaigns should focus on the attractive prices of tourist services in Poland. This element is important for tourists from the researched countries as their household income is on average lower than the income of other European nations (data of Federal State Statistics Service 2020 and State Statistics Service of Ukraine 2020). Tourist organisations and tourist managers also have to stress the level of security when travelling across Poland. Our research shows that both Ukrainians and Russians positively assessed this aspect of Poland's image. This is an important factor, especially for families with children travelling for leisure purposes. Those responsible for marketing also need to find a way to influence Russian and Ukrainian tourists so that they choose Poland as a leisure destination. As research shows, even though the overall image of Poland is positive, tourists from the researched countries prefer spending time in different regions of the world.

Despite the originality of the study, it has its restrictions. Notwithstanding the relatively large number of respondents, the full representativeness of the research sample cannot be ensured, as those surveyed represented a limited number of regions, both in Russia and Ukraine. Some limitations also result from the character of the questionnaire. It was standardised and did not allow for the collection of qualitative data, which influenced the final conclusions drawn. Moreover, due to the explorative character of the study, the results should be treated as initial remarks that require further verification. It should be noted that the research on the perceived destination image of Poland was conducted from the demand perspective (visitor and non-visitor tourists). No research was conducted from the supply perspective (institutions related to organising and promoting tourism). This is definitely a limitation in formulating conclusions and requires further research.

This paper provides a substantive and methodological contribution to the research on shaping the image of a tourist destination. Some of the theses, especially the one regarding the image created by visitors and non-visitors, still need to be researched and verified in the future.

\section{ORCID}

Wioletta Kamińska (iD https://orcid.org/0000-0002-8770-9834

Mirosław Mularczyk (D) https://orcid.org/0000-0002-2372-2087

Magdalena Chrapek (D) https://orcid.org/0000-0003-2480-6124

Lidiya Dubis (1D https://orcid.org/0000-0001-5231-3920

Marta Malska (1D https://orcid.org/0000-0001-8887-6565

Evgeny Nesterov (1D https://orcid.org/0000-0003-2493-875X 


\section{References}

Aksoy, R \& Kiyci, S 2011, 'A destination image as a type of image and measuring destination image in tourism (Amasra case)', European Journal of Social Sciences, vol. 20, no. 3, pp.478488.

Anholt, S 2003, 'Brand new justice: The upside of global granding', Butterworth Heinemann, Oxford.

Araújo, A, Cardoso, L, Araújo, N \& Dias, F 2019, 'Understanding the role of destination imagery in mountain destination choice. Evidence from an exploratory research', European Journal of Tourism Research, vol. 22, pp. 151-165.

Assael, $\mathrm{H} 1984$, Consumer behaviour and marketing action, Kent Pub. Co., Boston.

Baloglu, S \& Mangaloglu, M 2001, 'Tourism destinations images of Turkey, Egypt, Greece and Italy as perceived by US-based touroperators and travel agents', Tourism Management, vol. 22, no. 1, pp. 1-9.

Baloglu, S \& McCleary, KW 1999, 'A model of destination image formation', Annals of Tourism Research, vol. 26, no. 4, pp. 868-897.

Beerli, A \& Martin, JD 2004, 'Tourists' characteristics and the perceived image of tourist destinations: a quantitative analysis - a case study of Lanzarote, Spain', Tourism Management, vol. 25, no. 5, pp. 623-36.

Boulding, KE 1956, The image: knowledge and life in society, University of Michigan Press, Ann Arbor.

Cardoso, L, Dias, F, de Araújo, AF \& Marques, MIA 2019, 'A destination imagery processing model: Structural differences between dream and favourite destinations', Annals of Tourism Research, vol. 74, no. C, pp. 81-94.

Cardoso, L, Vila, NA, de Araújo, AF \& Dias, F 2019, 'Foodtourism destinations' imagery processing model', British Food Journal, vol.122, no. 6, pp. 1833-1847.

Chen, CF \& Tsai, DG 2007, 'How destination image and evaluative factors affect behavioral intentions?', Tourism Management, vol. 28, no. 4, pp. 1115-1122.

Cherifi, B, Smith, A, Maitland, R \& Stevenso, N 2014, 'Destination images of nonvisitors', Annals of Tourism Research, vol. 49, pp. 190-202.

Crompton, JL 1979, 'An Assessment of the Image of Mexico as a Vacation Destination and the Influence of Geographical Location Upon the Image', Journal of Travel Research, vol. 18, no. 4, pp. 18-23.

De Jesus, J 2013, Visitor perception of destination image: a case study of Palestinian tourism, master's thesis degree programme in Tourism Management and Travel Management, London Metropolitan University, London.

Diaz-Rodriguez, P, Santana-Talavera, A \& Rodríguez- Darias, AJ 2013, 'Destination image, image at destination. Methodological aspects', Pasos. Revista de Turismo y Patrimonio Cultural, Special Issue, vol. 11, no. 3, pp. 83-95.

Echtner, CM \& Ritchie, JRB 2003, 'The meaning and measurement of destination image', The Journal of Tourism Studies, vol. 14, no. 1, pp. 37-48.

Fakeye, PC \& Crompton JL 1991, 'Image differences between prospective, first-time, and repeat visitors to the Lower Rio Grande Valley', Journal of Travel Research, vol. 30, no. 2. 10-16.

Federal State Statistic Service 2020. Available from: <www.gks. ru>. [10 January 2020].

Fuchs, M \& Pikkemaat, B 2004, 'Destination image analysisA cross-cultural segmentation approach'. Available from: www.researchgate.net/publication/330841068_Destination_ Image Analysis-A Cross-Cultural Segmentation Approach. [10 January 2020]
Gartner, WC \& Hunt, JD 1987, 'An Analysis of State Image Changeover a Twelve-Year Period (1971-1983)', Journal of Travel Research, vol. 26, no. 2, pp. 15-19.

Guba, EG (ed), 1990, The paradigm dialogue, Sage, London.

Gunn, CA 1972, Vacation scape: designing tourist regions, Taylor \& Francis, Washington.

Hair, JF, Anderson, RE, Tatham, RL \& Black, WC 1998, Multivariate data analysis, Englewood Cliffs, New York.

Jarvis, D, Stoeckl, N \& Liu, H 2016, 'The impact of economic, social and environmental factors on trip satisfaction and the likelihood of visitors returning', Tourism Management, vol. 52, no. C, pp. 1-18.

Joppe, M, Martin, DW \& Waalen, J 2001, 'Toronto's image as a destination: a comparative importance-satisfaction analysis by origin of visitor', Journal of Travel Research, vol. 39, no 3, pp. 252-260.

Kandampully, J 2000, 'The impact of demand fluctuation on the quality of service: a tourism industry example', Managing Service Quality, vol. 10, no. 1, pp.10-18.

Keller, KL 1993, 'Conceptualizing, measuring and managing customer-based brand equity', Journal of Marketing, vol. 57, no. 1, pp. 1-22.

Kim, H \& Richardson, SL 2003, 'Motion picture impacts on destination images', Annals of Tourism Research, vol. 30, no. 1 , pp. 216-237.

Konecnik, RM \& Gartner, WC 2007, 'Customer-based brand equity for a destination', Annals of Tourism Research, vol. 34 , no. 2, pp. 400-421.

Krippendorf, J 1982, 'Towards new tourism policies: the importance of environmental and sociocultural factors', Tourism Management, vol. 3, no. 3, pp. 135-148.

Kuhzady, S, Ghasemi, V \& Hashemi, S 2017, 'Pictorial analysis of the projected destination image: Portugal on Instagram', Tourism Analysis, vol. 24, no. 1, pp. 43-54.

Lawson, F \& Baud-Bovy, M 1977, Tourism and recreational development, The Architectural Press, London.

Lopes, SDF 2011, 'Destination image: origins, developments and implications', Revista de turismo partimonio cultural, vol. 9, no 2, pp. 305-315.

Martineau, P 1958, 'The personality of the retail store', Harvard Business Review, vol. 36, no. 1, pp. 47-55.

MacKay, KJ \& Smith, MC 2006, 'Destination Advertising: Age and Format Effects on Memory', Annals of Tourism Research., no. $33, \mathrm{pp} .7-24$

Pike, S 2002, 'Destination image analysis - a review of 142 papers from 1973 to 2000', Tourism Management, vol. 23, no. 5 , pp. 541-549.

Pike, S 2008, Destination marketing. An integrated marketing communication approach, Elsevier, Oxford.

Pike, S \& Ryan C 2004, 'Destination positioning analysis through a comparison of cognitive, affective, and conative perceptions', Journal of Travel Research, vol. 42, no. 4, pp. 333-342.

Polish Tourism Organisation 2020. Available from: <www.pot. gov.pl/pl/nowosci/wiadomosci-z-pot/rekordowy-rok-2017>. [10 March 2020].

San Martín, H \& Del Bosque, IAR 2008, 'Exploring the cognitiveaffective nature of destination image and the role of psychological factors in its formation', Tourism Management, vol. 29, no. 2, pp. 263-277.

Satysfakcja turystów [Tourists Satisfaction] 2015, Raport z badania przeprowadzonego przez PBS Sp. z o.o. na zlecenie Polskiej Organizacji Turystycznej [Report on the 
study conducted by PBS sp. z o.o. commissioned by Polish Tourism Organisation], РОT, Warszawa.

Stabler, MJ 1988, 'The Image of Destination Regions: Theoretical and Empirical Aspects', in Marketing in the Tourism Industry - the Promotion of Destination Regions, eds B Goodall, G Ashworth, Routledge, London, pp. 133-159.

State Statistics Service of Ukraine 2020. Available from: <www. ukrstat.gov.ua>. [10 March 2020].

Sukiman, MF, Omar, SI, Muhibudin, M, Yussof, I \& Mohamed, B 2013, 'Tourist satisfaction as the key to destination survival in pahang', Proceedia-Social and Behavioral Sciences, vol. 91, pp. 78-87.

Sztabiński, F 2003, 'Logika badacza i logika respondenta problem adekwatności narzędzia badawczego' [Research logic and respondent's logic - problem of research tool adequacy], Ask: Research and Metods., vol. 12, no. 1, pp. 147-175.

Tarka, P 2015, 'Własności 5-cio i 7-mio stopniowej skali Likerta w kontekście normalizacji zmiennych metodą Kaufmanna i Rousseeuwa' [Properties of the 5-point and 7-point Likert scale in the context of variables normalization using Kaufmann and Rousseeuw methods], Prace Naukowe Uniwersytetu Ekonomicznego we Wrocławiu [Research Papers of Wrocław University of Economics and Business], no. 385 , pp. 286-295.

Thomas, WJ \& Thomas, D 1928, The child in America: behavior problems and programs, Alfred A. Knopf, New York.

World Travel and Tourism Council, 2018. Available from: https:www//wttc.org/. [08 November 2018].

Xesfingi, S, Papadopoulou, G, Karamanis, D \& Martens, HM 2018, 'Visitors satisfaction in Dubai and pre-trip destination image', MPRA Paper, 89850. 